\title{
KNOWLEDGE NEEDS IN RURAL TOURISM IN CZECH REPUBLIC
}

\author{
Ludmila Dömeová \& Rudolf Zeipelt \\ Czech University of Life Sciences in Pague Kamýcká 12916500 Praha 6 Tel.+420224382181 \\ domeova@pef.czu.cz
}

\begin{abstract}
Rural tourism has gone through an important development, but in the Czech Republic has only been possible to run a private business only in last 18 years. In Czech Republic that form of tourism is not very widespread, although there is great potential in it and the neighboring countries such as Austria or Germany are on a much higher level. For more intensive development and better competitiveness on the marker a proper education is necessary especially on the secondary level. An inquiry investigation has been provided. The responders were owners and operators of small businesses in rural tourism. The first part of the questionnaire was focused on the matters of ownership, running the business, promotion, internet services, etc. The subsequent part of the questionnaire gathered the information about the capacity of the places, the types and prices of accommodation, and the facilities. It also surveys the surroundings of the place - both natural and cultural sights. The survey has brought interesting facts about the level of the rural tourism of selected regions. The inquiry investigation was made by trained persons who gathered much information above the framework of the questionnaire. Many demands and complains were concerned with lack of specialized education, needs of new study programs and branches. There are many specifics of this branches, the most important is that there are more than $90 \%$ of micro firms. If we want to keep the special features of the rural tourism we have to prepare future entrepreneurs and employees in completely different way than those for big hotels, spas or congress centers. The contribution deals with the present status of rural tourism in Czech Republic and the educational need of the people involved.
\end{abstract}

Key words: Rural Tourism, Inquiry Investigation, Knowledge Needs, Micro Business

\section{Introduction}

The rural tourism is not a completely new issue. The interest in this type of recreation was recognized since $19^{\text {th }}$ century and is connected with the period of Romanticism. The modern form of rural tourism came into existence in the second half of the $20^{\text {th }}$ century.

The political and economical situation in Czech Republic was not favorable to any kind of private business including tourism.

The development of rural tourism in all countries is closely connected with the development of small private farms and other small freeholders in countryside.

Czech agriculture after 1948 went through a forced nationalization. The result was the constitution of a small number of big state or co-operative farms. Many qualified people moved out (sometimes unwillingly). Even worse was the situation in border regions which have the best natural conditions for tourism. The original German population was displaced after World War II; the incomers were often not able to take care of the farms. Large acreage was taken over by state farms or there were constituted military areas with agriculture land and forests under control of a huge company "Military farms and forests".

In this period many city people acquired their own recreation facilities. In these weekend houses they spent majority of their free time often as an escape from bounded life in socialist reality.

Many firms also owned their own recreation facilities. During holidays they gave them up to their employees for recreation; in the rest of the year they used them for meetings, seminars, etc.

After 1989 part of the agriculture land and other facilities went through privatization and in ideal cases (there were many legal problems) was returned to the original owners or their children. Only a small part of these old-new owners were able and willing to run a small farm. Many farms remained of the same size; there was only change in the ownership and legal status of the firm (change from state or co-operative farms into joint stock companies). The whole agriculture sector went through industrialization and concentration to improve the effectiveness of the production and profitability of the companies (Houška, Beránková, 2008).

The few private farmers who started their own business in small private farms have gone through very difficult times. Those who survived are now more stabilized (some of them with the help of the EU) and many of them are trying new methods of farming especially production of ecological products and home made foodstuffs. These small farms have the best potential for rural tourism and some of them really have started the business in this sector. 
The customers' demand has also changed. The majority of the firm recreation capacities were sold because the firm did not take care of them or the firms themselves became extinct. All Czech people were excited by the possibility to travel abroad which they did not have before 1989. They began to travel to seaside places abroad; highly popular have become trips to well known places in Europe and overseas. The possibilities for recreation at home country were neglected. Moreover, people preferred to stay in their own recreation houses if they decided to spend holidays in the Czech Republic.

On the other hand the Czech Republic opened its borders for tourists from abroad and the interest was really high, much over the disposable capacities (Šimková, 2000). Sad to say, the interest of investors concentrated only to high standard hotels mainly in Prague. The Czech countryside has been discovered latter in remarkably lower scale.

The rural tourism has been growing only in several recent years when the domestic demand raised unfortunately probably due to deterioration of global economical situation and lowering incomes of Czech citizens.

Because the rural tourism in Czech Republic has gone through non-continuous development and for many years was in fact only a part of a shadow economy there are not enough information in this field. It is necessary to map the situation in order to get effectual support from local, state and European institutions.

\section{Goals and methods}

The goal of this contribution is to determine the status of rural tourism in chosen regions of the Czech Republic. This will be followed by showing the imperfections, problems and potential possibilities of this form of tourism.

The information was gained in a questioner investigation focused on owners or operators of the object of rural tourism.

The questioner investigation is very effective method which enables the researches to get answers from many respondents with relatively low costs. The authors choose a method of a standardized interview with a question form. The method guarantees that the information from all responders are of the same type; all responders are asked the same questions in the same order.

The research file consisted from objects of rural tourism in chosen regions of Czech Republic. In the first phase the regions were chosen and than the object by random selection. This method makes possible to generalize the results.

The total number of respondents was 77 , resp. 75 because two forms were not properly filled in. The data collection was realized by interviewers which led to better validity of data and higher percentage of returned filled in forms.

After collection of the question forms the open questions were encoded and than all answers were processed. The formal and factual check of the data was implemented. The data was prepared for analysis."

An explorative analysis was realized as a first. This analysis is useful for detail investigation of the data structure.
In the second step the relative frequencies of answers were calculated for basic orientation in the data file. In the third step marks with possible dependencies were defined. The analysis of contingency tables was applied for investigation of possible relations. A test of dependency was carried out in these tables. If the marks were proved as dependent the tightness of the dependency was verified.

\section{Results and discussion}

\subsection{Business and labor}

In most cases the object is owned by the responder and a member of his/her family $(45 \%)$. The majority of respondents $(90 \%)$ has a trade license and run a business as a physical person. The average time being in business is 9 years that means the sector is very young. The hypothesis: „Women do majority of works connected with touristic services" was proved - see Tab. 1 .

Tab. 1. Share of men and women in touristic services

\begin{tabular}{|l|c|}
\hline Who works & Relative frequency \\
\hline Women & 53,3 \\
\hline Men & 26,7 \\
\hline Both & 6,7 \\
\hline Answer missing & 13,3 \\
\hline
\end{tabular}

The number of women employed is very important because nearly all of them are able to combine work in the tourist service with care of small children, families, seniors, handicapped people, etc. The rural tourism is a great opportunity for them to find a job close to their homes.

\subsection{Services and specifications}

The tourism somehow connected with agriculture production is in $27 \%$ of objects but only in $16 \%$ there are homemade products for sale. Eco agro tourism is $27 \%$ in of object and the firm tourism in $22 \%$. Only about one half of object offer also some form of boarding. - see Tab. 2 .

Tab. 2. Food services

\begin{tabular}{|l|c|}
\hline Type of service & Relative frequency \\
\hline Cold and hot meals & 45,1 \\
\hline No & 47,9 \\
\hline Supply of foodstuffs & 8 \\
\hline Answer missing & 5,3 \\
\hline
\end{tabular}

It is often possible to park near the house (95\%) and bring pets $(80 \%)$. In some objects there are also some specific facilities as:

$\begin{array}{ll}\checkmark \text { ski store } & -34 \%, \\ \checkmark \text { children's playground } & -39 \%, \\ \checkmark \text { table tennis } & -31 \%, \\ \checkmark \text { outside swimming pool } & -24 \% \text {. }\end{array}$


The accessibility of the objects by public transport is good. The average distance to a bus stop is $1 \mathrm{~km}$ and $6 \mathrm{~km}$ to a train stop. Many localizers are ready to pick up their guests $(68 \%)$ or at least transport their luggage $(48 \%)$. The distance to the nearest post office, medical center, fast food and restaurant is $5 \mathrm{~km}$ in average.

In following question the accessibility of various recreation capacities as an open air pool, ski lift, roofed swimming pool, spa, ski and bicycle rent, ski school and golf course was investigated. The important distance was $20 \mathrm{~km}$. If the capacity is within this distance it is rated as available. The percentage of positive answers (it means it is available) was $60 \%$. Nearly the same result $(60 \%)$ was with availability of cultural amenities, cultural and natural places of interest and doings as: natural preservation, castle, ruin, observation tower, chateau, cinema, theatre, concert, festival, ball, discotheque, etc.

\subsection{Promotion, reservations and payments}

The promotion is very important for getting customers. Some object are in catalogues of travel agencies but majority of customers is gained through the Internet (82\% respondents). The other successful ways are personal contacts, friends and repeated visits (57\%), information centers (40\%), travel agencies $(21 \%)$, hangers $(15 \%)$ and insertion in newspapers (13\%).

Communication with customers is also important. $91 \%$ of responders has own mail address, $87 \%$ has own WebPages and a link placed on some touristic portal exists for $83 \%$ of objects. Remarkably lower number are connected with online reservations (38\%) and on-line

payments $(17 \%)$. The providers are not much interested in these services and also automatic reservation systems are not very popular - see Tab. 3 .

Tab. 3. Reservation methods

\begin{tabular}{|l|c|}
\hline Method & Relative frequency \\
\hline Hand made remark in calendar & 45,3 \\
\hline $\begin{array}{l}\text { Send post money order, a deposit } \\
\text { must be paid in advance }\end{array}$ & 4 \\
\hline Purchased a professional system & 2,7 \\
\hline Own system & 28 \\
\hline Other & 10 \\
\hline
\end{tabular}

\subsection{Dependency measures}

The dependency between answers was studied for several questions. A pivot table was always created for these questions and the dependency of marks was investigated by statistical tests (̌̌ezanková, 2005; Hindls et al.,1999).

In the cases when the dependency was proved the contingency coefficients were calculated. Some more detail descriptions of dependency follows.

There is a dependency between opinion that the object is situated in a recreation area and tourism is a main source of income. The dependency is medium with the value of the contingency coefficient is 0,458 . The source of main income is also in correlation with natural and cultural places of interest. The dependency is again medium; the correlation coefficients are 0,445 and 0,414.

The following Table 4 shows the dependency of income from tourist services on other factors.

Tab. 4. Dependency between income and chosen factors

\begin{tabular}{|l|c|c|c|}
\hline Question & $\begin{array}{c}\text { Dependency } \\
\text { exists }\end{array}$ & $\begin{array}{c}\text { Contingency } \\
\text { coefficient }\end{array}$ & Cramer's V \\
\hline Offer of firm tourism & Yes & 0,487 & 0,558 \\
\hline Plans for changes in services & Yes & 0,383 & 0,415 \\
\hline Plans for further equipment & Yes & 0,384 & 0,415 \\
\hline $\begin{array}{l}\text { Offer family celebration, sport } \\
\text { events, etc. }\end{array}$ & Yes & 0,520 & 0,430 \\
\hline Rental of sports equipment & Yes & 0,466 & 0,320 \\
\hline
\end{tabular}

The dependency was proved for all factors; the dependency is medium or mesoscale.

Another investigated dependency was the existence of an income from an agriculture production and other chosen questions. A mesoscale dependency was proved for sale of the own products (contingency coefficient 0,505) and for operating agro-tourism (contingency

coefficient 0,445 ). There is a medium dependency with usage of the object for a whole year (contingency coefficient 0,332 ) and operation of firm tourism (contingency coefficient 0,323 ).

The following table 5 shows the dependencies between tourism connected with agriculture production and other chosen questions.

Tab. 5. Dependency between tourism combined with agriculture and chosen factors

\begin{tabular}{|l|c|c|c|}
\hline Question & $\begin{array}{c}\text { Dependency } \\
\text { exists }\end{array}$ & $\begin{array}{c}\text { Contingency } \\
\text { coefficient }\end{array}$ & Cramer's V \\
\hline The object is used whole year & Yes & 0,260 & 0,269 \\
\hline We sell own products & Yes & 0,305 & 0,320 \\
\hline Eco-agro-tourism & Yes & 0,603 & 0,759 \\
\hline $\begin{array}{l}\text { I am interested in education } \\
\text { activities }\end{array}$ & Yes & 0,398 & 0,430 \\
\hline Offer of foods & Yes & 0,408 & 0,447 \\
\hline Organization of firm seminars & Yes & 0,332 & 0,352 \\
\hline Rental of sports equipment & Yes & 0,392 & 0,426 \\
\hline
\end{tabular}

The results in the Tab. 5 show that running a touristic object in combination with agriculture widen the offer of the objects and makes the object more interesting and possibly also the occupancy and earnings will be higher. Naturally the highest scale of dependency is for agro tourism. The dependency for other factors is medium.

The search for dependencies between the interest in educational activities and other questions disclosed dependencies between combination with agriculture, ecoagro tourism and firm tourism. These dependencies are mesoscale. 


\section{Conclusions}

The pilot investigation on present status of rural tourism in Czech Republic brought some interesting results:

The sector is relatively very young; developing in last ten years.

The firms are small, usually owned by private persons and families.

Mostly women are working in touristic services.

The services offered and equipment are satisfactory in average; many owners plan improvements.

The environment is suitable; many places of interest are attainable.

We see opportunities in better promotion and marketing of the services. Higher number of customers is desirable but it calls for improvement of reservation and payment systems. It is necessary to face immediately the raising interest from Czech customers which is now coming together with worse economical situation. By our opinion it is an opportunity to gain new customers but it is necessary to do something to keep them.

Generally wider range of services offered also raises the number of customers. Many activities can be connected with the agriculture production. The best way is to make up new services, to come sometimes with something new and modern, to broaden the chance to spend active and interesting holidays.

The recreation potential of Czech Republic is high and has not been discovered in many places. So far the interest of touristic business has focused mainly to the capital Prague and several best known places as Český Krumlov or Karlovy Vary.
The Czech countryside is able to offer unforgettable experiences and adventures as well as days spend in calmness and wellbeing. The first who must be aware of this fact are the locals.

\section{Acknowledgment}

The paper is supported by the grant project of the Ministry of Local Development of the Czech Republic No. WD-12-07-2 - "Definition of suitable areas for development of rural tourism and exploitation of the objects for firm tourism".

\section{Literature}

R. Hindls - S. Hronová - I. Novák (1999): Data analysis in managerial decision making. Grada Publishing. Prague, ISBN 807169-255-7 (in Czech).

M. Houška - M. Beránková, (2008): Innovative Interface for Knowledge Potential Development in Regions of the CR. Conference Countryside - Our World 2008. ZU Prague 2008, pp. 28-35 ISBN 978-80-213-1772-7.

H. ̌̌ezanková (2005): Analysis of Cathegorial Data. College of Economy Prague. ISBN 80245-0926-1 (in Czech).

E. Šimková (2000): Competition and its evaluation through balance of weak and strong features. $E+M$ Economy and Management, III., No. 2, s. 32-34. ISSN 1212-3609. (in Czech). 